\title{
Online readiness in universities from disabled students' perspective
}

\author{
Eulàlia Hernández Encuentra \\ ehernandez@uoc.edu \\ Universitat Oberta de Catalunya, Spain \\ Elena Barberà Gregori \\ ebarbera@uoc.edu \\ Universitat Oberta de Catalunya, Spain
}

\begin{abstract}
The aim of online universities is to increase learning accessibility for all students. After some years of existence, online higher education should be analysed in terms of its preparedness to meet the learning needs of people with disabilities. This paper presents a study that sheds light on the level of readiness of online higher education institutions by examining students' views of a well-established online university, using a research-based questionnaire. The research involves all students with disabilities studying at the Open University of Catalonia (UOC), with an effective participation of 421 students. The conclusion of the paper is generally highly positive concerning the extent to which the university has overcome barriers and provided satisfactory academic accommodations. However, the results do indicate a need for a more comprehensive and specific solutions for dealing with unmet needs, especially for those students with mental disabilities.
\end{abstract}

\section{Keywords}

Disability; online higher education; accessibility; academic accommodations. 


\section{Introduction}

Online learning environments provide a good way for people with disabilities to access higher education. These environments have been shown to be effective and favoured by students with disabilities, as evidenced by the recently increasing numbers of these students enrolling on online courses (Verdinelli \& Kutner, 2016). Online programs can help students with disabilities overcome some of the major obstacles they face when completing graduate education, such as stigmatization, low perceived capacity and accessibility issues connected to their impairment. Although online learning gives these adult learners more control over the learning process, numerous barriers continue to impede regular access to higher education. In this context, the universal design for instruction (Tobin, 2014; Cindy, Dell, \& Blackwell, 2015) applied to online learning has, so far, been insufficient in dealing with the wide range of impairment situations and the extensive and rapidly obsolescent technology repertoire (Whetstone, 2017).

It is essential that online education providers strive to provide a suitable response to the main needs of students with disabilities when accessing online education. They must also understand the factors affecting their access and offer solutions.

In this article focused on accommodations, we refer to students reporting about their own disabilities being aware that this expression is aligned with an individual model of disabilities (Waterfield, Beagan, \& Weinberg, 2018; Griful-Freixenet et al., 2017). This approach makes it easier to compare the results with those of previous studies.

\section{a. Factors influencing performance}

The latest studies investigating the factors that impact the performance of students with disabilities in an online learning environment reveal three kinds/levels of results:

- Persistence factors: include not only more personal aspects, such as resiliency, selfdetermination, motivation and goal commitment, but also institutional assistance and other external sources of support (Verdinelli \& Kutner, 2016).

- Teaching factors: involve teacher and social presences, and communication supporting interaction between students with disabilities and their instructors and impacting the students' perceived learning achievement and class satisfaction (Alamri \& Tyler-Wood, 2017; Roberts, Crittenden, \& Crittenden, 2011).

- Environmental factors: include learning management system accessibility and the situational circumstances of the immediate environment, such as family influence, health conditions (McManus, Dryer, \& Henning, 2017).

All these factors can impact positively or inhibit learning if they develop in one direction or another. Their potential impact is discussed in current literature in terms of barriers to or promoters of online learning in the first place, whereas the solutions are considered in terms of potential accommodations and online implementation.

\section{b. Institutional answers}

Even though the barriers to online education for students with disabilities can be largely associated with the type of impairment and personal and situational circumstances, most barriers described in the literature regarding external disability factors highlight the importance of the learning environment (McManus et al., 2017). 
It seems that, over time, online improvements will be implemented naturally, but the studies that have analysed the accessibility of top universities' websites have yielded surprising results, indicating that there were no significant improvements in the accessibility of university websites between 2005 and 2015 (Alahmadi \& Drew, 2017). Some of these studies add that there is a growing need for universities to commit to addressing the accessibility of online learning materials for students with disabilities (Alahmadi \& Drew, 2017; Jo et al., 2015). This situation shows that, in terms of performance and success, online universities have not yet achieved an appropriate institutional culture of accessibility and wider, more in-depth research is needed. (Betts et al., 2012).

Solutions to the diverse obstacles found in online study have been devised from the perspective of the institution and take the form of accommodations. The most common online accommodations are related to extending testing time in final evaluations and including assistive technologies. Also, the application of universal design is being used worldwide to reach all students (Pittman \& Heiselt, 2014) and being adapted to different types of impairments (Crow, 2008). Universal design focuses on presenting information in user-friendly ways in the online environment, offering multimodal alternatives for presenting information and providing choices in how students access and present information (Rogers-Shaw, Carr-Chellman, \& Choi 2018; UDI Online Project 2010).

However, universal design has been shown to be most effective when combined with an individualized design, which emphasizes proactivity over being respondent to the needs expressed (Griful-Freixenet et al., 2017).

\section{c. E-readiness of online universities for students with disabilities}

Another source and approach that provides critical insight into how e-learning university programs can be successfully implemented for the benefit of all students is research into e-readiness. Last decade, numerous studies have been conducted regarding e-learning readiness in higher education (for a review, see Mosa, Mahrin, \& Ibrrahim, 2016). These studies mostly focus on technology, followed by human-financial resources and content. Much of the research has been performed in specific cultural contexts (Kenya: Oketech, Njihia, \& Wausi, 2014; Thailand and the USA: Saekow \& Samson, 2011) and only some research focuses on accessibility as a specific element (South Africa: Mafenya, 2013).

One of the most up-to-date reviews of e-learning readiness in higher education (Mosa et al., 2016) presents 16 influential factors. Most of these factors correspond to macro-level phenomena and are institutionally oriented (technology, human resources and regulations, among others); four of them are mostly related to teaching (e.g., training procedure and pedagogy) and only one could be considered closer to a micro-level phenomenon or to students (learners and acceptance of learning). There appears to be a lack of research in the field and a clear gap has been identified in the knowledge of the factors that shape e-readiness (Mosa et al., 2016). Complementarily, other studies have identified the skills and attitudes that are influential variables (Rohayani, Kurniabudi, \& Sharipuddin, 2016).

In order to identify and understand the key components that contribute to the general success of e-learning among all kinds of learners, we need to assess the extent to which e-learning programs have been effectively implemented, particularly in terms of accessibility 1 for students with disabilities. Our aim is to collect more data not only about whether these core factors score satisfactorily in an external assessment but, more importantly, what further improvements in

1 Accessibility refers to inclusive design that strengthens interaction between the user and the web-based design. It requires attention to technology in terms of usability for all but also the psychological appropriateness of the teaching material presented (Arachchi, Sitbon, \& Zhang, 2017). 
accessibility should be made from the perspective of students with disabilities. We argue that specific accessibility factors for students with disabilities should be included in e-readiness assessment models and not merely applied to access to technological resources (Lopes, 2007).

Hence, beyond technological and institutional factors influencing online learning for students with disabilities that have already been considered, the present study seeks to reveal other possible aspects from the students' perspective through the use of open-ended questions in an online survey. The study aims to shed light on any as yet unidentified factors that may exist by analysing the improvements proposed by current online students with disabilities and helps us grasp the extent to which the online university setting is ready to embrace the alternatives put forward by the students.

The research questions driving the present research are as follows:

- Which barriers to access do students with disabilities face at an online university?

- What are the most common academic accommodations in an online university?

- What are the unmet needs in an online university and how can they be tackled from a student's perspective?

\section{Methods}

Hence, In Spain, the government manages the services and support for students with special needs at primary- and secondary-school level. However, with regard to universities, it only provides general legislation and guidelines. Universities have therefore created, at national and regional level, networks of support - sponsored by the government - to set up common criteria and protocols and share best practices.

The Open University of Catalonia (UOC), located in Spain, can be considered an archetypical online university, based on asynchronous learning, and is the top university in terms of the number of students with disabilities in the Catalan university system, and the third at national level. Accordingly, it has designed an Accessibility Program to both establish guidelines and create the mechanisms to achieve a truly inclusive university, which deal with issues such as improving campus accessibility, adapting non-accessible learning resources, promoting the raising of awareness and education among staff members (administration and faculty) and increasing the number of cooperation agreements with organizations that promote the workplace insertion of people with disabilities, among others. The Accessibility Program coordinates the activities of an interdisciplinary working group comprising accessibility leaders and the Curricular Adaptation Committee.

\section{a. Participants}

Participants reported that they had a disability during the enrolment process. By providing an official disability certification, they were eligible for a discount on tuition fees and were exempt from paying the normal public price for academic credits.

Out of 421 participants, almost half of whom were women (51\%), 86.2\% were adults from 30-60 years old (30-35: 43.1\%, and 45-59: 43.1\%), 10.7\% were below 29 years old and $3.1 \%$ were under 60 years old. Participants had different university access profiles (ranging from primary school education to PhDs). Among them, $80 \%$ had already followed university studies, being UOC 
their option to life-long learning. Only $18.5 \%$ of the participants had accessed their current studies after only completing secondary-school or primary-school education (1.4\%).

Disabilities related to mobility and different diseases (i.e., pain and cardiac and breathing problems) are the most prevalent among the students with disabilities, accounting for $36.8 \%$ and $25.9 \%$, respectively. Other causes of impairment are sensorial disabilities (hearing, vision and multiple disabilities) (14.9\%) and mental illnesses (14.7\%).

Participants were studying different bachelor's and master's degrees in a wide range of areas (Health Sciences: 19.5\%; Law and Politics: 18.5\%; Science and Engineering: 15\%; Business and Economics: 14.7\%; Arts and Humanities: 13.3\%; Education: 10.7\%; Communication: 6.2\%; Language School: $0.2 \%$; Other/NA: $1.8 \%$ ). Most of the students had been enrolled at the current university for two academic years or more; specifically, $0-1$ years: $28.1 \%, 2-5$ years: $47.7 \%$, over 6 years: $24.2 \%$.

More than half of the reasons for choosing an online program were related to the possibility of reconciling work, family and personal life (the reasons cited included no time constraints, having multiple responsibilities, autonomy, etc.), and just one person cited reasons relating to avoiding stigma. Interestingly, one out of four considered that the e-learning context was a scenario that was already adapted to their needs, as we will show in the next section.

\section{b. Instrument}

The study employed a survey based on the one used in an unpublished international comparison of access to e-learning for university students with disabilities.

The survey was distributed online using a Google sheet platform with an upgraded degree of security for companies and organizations. It comprised 24 closed-ended and four open-ended questions covering five aspects: demographics; knowledge and use of the accommodations offered by the university in relation to disabilities; disclosure; specific problems with online platforms in relation to the student's studies; and recommendations for improving accessibility in the UOC's learning environment in terms of teaching and materials. Additionally, the survey asked about the students' willingness to participate in further stages of the study (see appendix).

\section{c. Procedure}

An invitation to participate in the survey was emailed in October 2017 to 1,172 students who had reported having a disability during the enrolment process. They received the documents (invitation, link to the informed consent form and the online survey, and an attached document with basic information about the project) in the language in which they had previously requested receiving notifications from the institution. A week later, a reminder was emailed to the students, making the survey available for two weeks in total. At the end of this period, the response rate was $35.92 \%$, which is much higher than expected for an online questionnaire (Nulty, 2008).

\section{d. Data Analysis}

The analysis comprises descriptive statistics for closed-ended questions and a qualitative codification for the open-ended questions. Codification was carried out based on the answer options to question 8a (see appendix) on the type of adaptations offered by the university: content adaptations; format of learning materials; teacher support and assistance; assessment activities; exam/virtual test; technology support; other. 
Cohen's kappa coefficient, and the inter-coder agreement was $82.8 \%$.

\section{e. Ethics}

Approval was obtained from the UOC's Ethical Committee in October 2017. The survey included an explicit informed consent form; therefore, by submitting the survey, participants consented to taking part in the study.

\section{Results and Discussion}

\section{a. Study of barriers}

A first step to better understanding barriers that students with disabilities find in the framework of an online university is to examine their level of attainment and reasons for choosing an online university. Our research verifies that the number of years spent studying and the performance of online students who report disabilities (almost $3 \%$ of the total amount of students at the university) are similar to those of students overall, as reflected in their final grades (Table 1 ). These results are consistent with those found by Knight, Wessel, and Markle (2018), showing that students with disabilities obtain similar results to those of all other students, despite their fear of not finishing their studies (Lee et al., 2015). Moreover, the reasons given for selecting online studies are homogenous with those reported by the majority of students, which, at the same time, correspond to those identified in recent literature reviews (Ilgaz \& Gulbahar, 2017). All these data do not line up exactly with baseline general conditions but rather with the effectiveness of online studies for all online learners (Table 2).

\begin{tabular}{|l|l|l|l|l|}
\hline \multicolumn{2}{|l|}{ Students } & \multicolumn{2}{l|}{ Students reporting disability } \\
\hline & $\begin{array}{l}\text { Bachelor's } \\
\text { degrees }\end{array}$ & Master's degrees & $\begin{array}{l}\text { Bachelor's } \\
\text { degrees }\end{array}$ & Master's degrees \\
\hline $\begin{array}{l}\text { Number of } \\
\text { credits enrolled } \\
\text { on (mean) }\end{array}$ & 25.9 & 25.7 & 24 & 23 \\
\hline $\begin{array}{l}\text { Number of } \\
\text { semesters to } \\
\text { graduate }\end{array}$ & 10.6 & 3.7 & 10.2 & 4 \\
\hline $\begin{array}{l}\text { Performance } \\
\text { rate1 }\end{array}$ & $74.3 \%$ & $88.2 \%$ & $66.6 \%$ & $80.5 \%$ \\
\hline $\begin{array}{l}\text { Success rate2 } \\
\text { 1 Performance rate: number of credits passed in relation to the number of credits enrolled on. } \\
\text { 2 Success rate: number of credits passed in relation to the number of credits actually taken. }\end{array}$ \\
\hline
\end{tabular}

Table 1. Comparative index on academic achievement (2016/2017 academic year) 


\begin{tabular}{|l|l|}
\hline Reasons & $\%(\mathbf{n})$ \\
\hline No timetable constraints & $30.6(129)$ \\
\hline $\begin{array}{l}\text { Having multiple } \\
\text { responsibilities }\end{array}$ & $27.8(117)$ \\
\hline Proved adaptation & $25.7(108)$ \\
\hline $\begin{array}{l}\text { Autonomy (not related to the } \\
\text { disability) }\end{array}$ & $13.5(57)$ \\
\hline Avoiding social rejection & $0.2(1)$ \\
\hline Own study rhythm & $0.2(1)$ \\
\hline Other /NA & $1.9(8)$ \\
\hline
\end{tabular}

Table 2. Reasons for online learning choice (students reporting disability)

Another interesting result regarding the barriers students with disabilities face when accessing and studying at an online university is the fact that $77.7 \%$ report that they can follow the online studies normally and have never dropped out, and only $22.3 \%$ of the students report having some kind of problem. Up to $15.4 \%$ of this quarter of students $(n=65)$ have at some time abstained from continuous assessment or dropped out of a subject before the final assessment due to a lack of accessibility to the system, the teaching or the learning materials. Barriers or problems described for this quarter of students are diverse, but more than half are related to a lack of time to complete the academic tasks and the characteristics of their disability. Problems related to academic materials were of particular significance $(14.1 \%)$ (Table 3 ).

\begin{tabular}{|l|l|}
\hline Problems described & \% (n) \\
\hline Lack of time & $27.5(35)$ \\
\hline Characteristics of the disability & $25.9(33)$ \\
\hline Academic materials & $14.1(18)$ \\
\hline Virtual Campus & $6.2(8)$ \\
\hline $\begin{array}{l}\text { Cognitive (comprehension and } \\
\text { concentration) }\end{array}$ & $6.2(8)$ \\
\hline Collaborative activities & $5.5(7)$ \\
\hline A foreign language & $4.7(5)$ \\
\hline External factors & $2.3(3)$ \\
\hline Mental illness & $2.3(3)$ \\
\hline Physical barriers in face-to-face events & $1.5(2)$ \\
\hline Loneliness & $0.7(1)$ \\
\hline Teaching (unspecific) & $0.7(1)$ \\
\hline Academic calendar & $0.7(1)$ \\
\hline Communication & $0.7(1)$ \\
\hline
\end{tabular}

Table 3. Problems described (students reporting disability) 
The low number of students with disabilities requiring assistance reveals, to some extent, that the level of accessibility to the online studies could correspond, to some degree, with the type of disability. This finding led us to study this matter in depth, relating the type of disability with the problem stated (Table 4). It was discovered that problems concerning the need for extended testing and activity completion time were often reported as relating to the characteristics of the illness/disability (i.e., an acute episode or the continuous need for rest or to stop doing an activity).

\begin{tabular}{|c|c|}
\hline Disability (n) & Major problems stated \\
\hline Medical (107) & $\begin{array}{l}\text { Time } \\
\text { Characteristics of the illness (time) } \\
\text { Academic materials } \\
\text { Virtual Campus }\end{array}$ \\
\hline Sensitive (hearing) (33) & $\begin{array}{l}\text { Academic materials } \\
\text { A foreign language } \\
\text { Learning pace/time }\end{array}$ \\
\hline Sensitive (visual) (27) & $\begin{array}{l}\text { Virtual Campus } \\
\text { Cognitive (comprehension and } \\
\text { concentration) } \\
\text { Collaborative activities } \\
\text { Time }\end{array}$ \\
\hline Mobility (25) & $\begin{array}{l}\text { Time } \\
\text { Characteristics of the illness (time) } \\
\text { External factors }\end{array}$ \\
\hline Mental (22) & $\begin{array}{l}\text { Time } \\
\text { Characteristics of the illness (time) } \\
\text { Loneliness } \\
\text { Stigma/disengagement }\end{array}$ \\
\hline Brain injury (8) & $\begin{array}{l}\text { Time } \\
\text { Communication }\end{array}$ \\
\hline Learning disability (4) & $\begin{array}{l}\text { A foreign language } \\
\text { Cognitive (comprehension) }\end{array}$ \\
\hline Intellectual (2) & Cognitive (concentration) \\
\hline Multisensorial (2) & Academic materials \\
\hline
\end{tabular}

Table 4. Problems stated by disability

To gain a better understanding of the results, data should probably be considered in relation to the adjustments and modifications made for students with disabilities if required. 


\section{b. Study of Accommodations}

A first University students with disabilities who experience problems studying online have the right to ask for accommodations adapted to their learning needs. The most common adjustments offered to them by online institutions are related to infrastructures or instructional elements (Kutscher \& Tuckwiller, 2018). These accommodations are usually made on individual basis after analyzing each case separately, although the university has protocols to be activated in similar cases to ensure that it acts cohesively.

Previous studies (Newman \& Madaus, 2014) have shown that fewer than $50 \%$ of students disclose that they have a disability and most of them are satisfied with the accommodations they receive once they ask for them (Kutscher \& Tuckwiller, 2018).

Thus, in our case, $40.14 \%$ of the students with disabilities received accommodations by requesting them from the university and reported a high level of satisfaction in terms of them adequately meeting their needs ( $78.9 \%$ stated that accommodations were mostly or always adequate) (see Table 5). Those accommodations were mostly related to having more time, technological support or architectonic/furniture support during the final tests when face-to-face $(30 \%)$ or related to teaching support during the course, for example, asking for a time extension to complete learning activities (20.8\%). Technological adaptations during the course were also highlighted $(8.9 \%)$, followed by adjustments to the materials (5.9\%) content (3.9\%) or assessment activities $(3.4 \%)$. The "others" option (24.3\%) gave specific examples of the other categories (i.e., having a lefthanded chair, audiobooks or more time for specific activities) and provided two new pieces of information: turning the Virtual Campus into a "textualised" web and meeting the needs resulting from mental illnesses.

\begin{tabular}{|l|l|}
\hline $\begin{array}{l}\text { Satisfaction } \\
\text { level }\end{array}$ & $\begin{array}{l}\text { \% ( } \mathbf{n}) \\
\text { (only those who } \\
\text { received them) }\end{array}$ \\
\hline Always & $63.7(109)$ \\
\hline Mostly & $15.2(26)$ \\
\hline Sometimes & $19.2(33)$ \\
\hline Never & $2.3(4)$ \\
\hline
\end{tabular}

Table 5. Satisfaction with the accommodations received

The students' comments for the open-ended questions provided extra information about the adequacy of the accommodations, which included having more time for assessment activities (continuous or final tests), empathy and fluent communication with the teachers, the need for specific technological accommodations to the academic materials and the recognition of particular characteristics of a specific disability and the learning needs resulting from it (Fin, 1998).

Regarding the second objective, which focuses on the range of academic accommodations available at an online university, it can firstly be said that although the students have the right to academic adaptations, many students reported that they were unaware of the possibility of asking for help (30.2\% and $34.7 \%$ who were unsure). These results, in line with previous literature (Kutscher \& Tuckwiller, 2018), open a window for the university to increase awareness of the online support services available, taking into consideration the satisfaction felt when a particular accommodation is obtained. Nonetheless, around half of the total students stated that they do not need any form of accommodation $(51.9 \%)$, and the ones who do mostly have motor $(38.3 \%)$, medical $(22 \%)$, 
sensorial (22\%) and mental (9.3\%) disabilities. Furthermore, the most common accommodations reported by students with disabilities are related to final tests $(15.4 \%$, relating to aspects such as physical and environmental conditions) and teaching (10\% require extra time for online activities). Additionally, less commonly reported accommodations were adaptations to activities (1.7\%) and content $(1.9 \%)$. Around $10 \%$ of the students reported other accommodations, but these were specific examples referring to the above mentioned aspects (i.e., left-handed chairs, ramps, being alone in the exam room, specific time for going to the toilet and final tests with larger font size), or they repeated the information they had just given (see Table 6 for further information).

\begin{tabular}{|l|l|l|l|}
\hline \multicolumn{4}{|l}{ Accommodations made (\%) } \\
\hline Disabilities (n) & Not needed/ no courses & Some courses & Most/all courses \\
\hline Intellectual (0) & 100 & 0 & 0 \\
\hline Mental (8) & 87.1 & 4.8 & 8.1 \\
\hline Medical (19) & 81.6 & 8.3 & 10.1 \\
\hline $\begin{array}{l}\text { Sensitive } \\
\text { (hearing) (6) }\end{array}$ & 78.8 & 15.2 & 6 \\
\hline Mobility (33) & 78 & 8.4 & 13.6 \\
\hline Learning (1) & 75 & 25 & 0 \\
\hline $\begin{array}{l}\text { Sensitive (visual) } \\
(12)\end{array}$ & 55.5 & 25.9 & 18.5 \\
\hline Brain injury (6) & 50 & 0 & 50 \\
\hline $\begin{array}{l}\text { Multiple disabilities } \\
(1)\end{array}$ & 50 & 0 & 50 \\
\hline Multisensorial (1) & 33.3 & 33.3 & 33.3 \\
\hline
\end{tabular}

Table 6. Accommodations made by disability

\section{c. Study of unmet needs and solutions}

A first The third objective aims to reveal the recommendations which students with disabilities have, not only to know the degree to which the accommodation needs have been met, but also to improve accessibility in an online teaching and learning environment.

No research to date has monitored the impact of the accommodations provided on how students learn (Kutscher \& Tuckwiller, 2018). To some extent, asking students with disabilities about unmet needs and their satisfaction after receiving the accommodations might cover part of this gap.

In our study, when online students with disabilities were asked what their recommendations for improvement were, these were related to the learning environment, teaching and learning materials, among others. The answers are summarized in the following table (see Table 7). 


\begin{tabular}{|l|c|}
\hline Recommendation & $\%$ \\
\hline Technology support & 28.36 \\
\hline Learning materials (format) & 26.31 \\
\hline $\begin{array}{l}\text { Teacher support and } \\
\text { assistance }\end{array}$ & 19.5 \\
\hline Assessment activities & 8.77 \\
\hline Final tests & 7.01 \\
\hline Content adaptation & 1.16 \\
\hline Other / NA & 8.77 \\
\hline
\end{tabular}

Table 7. Summary of recommendations for improvement

Recent research offering solutions to ensure better accessibility to online studies and possibilities for following the courses gives similar answers to those listed in Table 7, although they tend to focus more on technological aspects (Fichten et al., 2009; Radovan \& Perdih, 2016). Raja (2016) talks about the "disability divide", where technology can help inclusion. The author presents the major barriers to achieving improvements, classified according to different aspects, and describes how ICT can be used to make the necessary changes. The results of our research show the major issues related to learning materials and technology support (see Table 7 for details). In addition, we have analyzed the details behind the "other" label. Although there is great variability, we have grouped the recommendations into five different aspects: bureaucracy (includes prices and enrolment processes), academic (teachers being previously informed about the needs of each student, time-adapted master's degrees, academic staff in contact with patient organizations to be better informed about how to deal with the specific needs and adapted curricula when a foreign language is cited as a problem), support (hotline and more information about the accommodations offered), empathy and communication (empathy with students with mental illnesses and positive discrimination toward them) and structural aspects (furniture and pre-reserved parking lots in public libraries).

\section{d. Study limitations}

Self-selection bias is one of the limitations of this study that might affect the representativeness of the sample, as well as the significance of the answers. Moreover, an invitation to participate in the study was sent at the beginning of the 2017/2018 academic year to all the students who had been enrolled in the 2016/2017 academic year; thus, although the reported data regarding their experience was still valid, the survey could have been answered by students who were no longer studying at the university.

To gain a clearer insight into whether inclusion practices in higher education institutions offering online learning are fulfilled, the study should extend its scope to those people with disabilities who do not reach university level yet would like to go. 


\section{Conclusions}

To assess to what extent an online higher education institution is prepared to embrace students with disabilities, we asked current students about their perceptions of and reality at a wellestablished online university. At first glance, it would seem that the online university offers students with disabilities an adequate service, as showed by the high level of preparedness reported, the low reporting of incidents, the low need for accommodations due to disabilities, and the absence of major problems with the technology platform.

Although there are different definitions of disability and huge variation in how it is recognized and followed up on (Leake, 2005), in our case, the acknowledgment of the disability appears clearly delimited by asking students to provide official certificates of disability. Even though this recognition only provides a certified label stating the percentage of disability, this procedure helps the university institution to build a "first-aid" support system, which, judging by the overall results, seems to work properly. A further step that could be contemplated to achieve greater and more adaptive educational intervention at the institutional level is to ask the students with disabilities for proper "documented needs" (Weis, Dean, \& Osborne, 2016) from the beginning. In other words, the institution should ask for a report describing the specific implications of the disability in terms of abilities and ensuing problems. This would imply a new role (and extra effort) for the official institution issuing the certification, because it would also require coordination between the institution (usually led by social services) and an official institution led by the education ministry to issue this kind of official expert opinion. Although this procedure is standard for primary and secondary education, it is not yet regulated at university level.

According to the mainstream literature and the results provided in this study, there are crucial aspects to be included in discerning the level of preparedness of an online university for students with disabilities. These aspects have shown to be valid for evaluating disability readiness at a generic level and they basically examine barriers, accommodations, recommendations and satisfaction from the perspective of the learner. However, revealing less evident elements to devise a possible measuring instrument could also lead to the inclusion of more detailed aspects that focus on equality of support according to disability, and may also involve obtaining relevant data from the institution (degree of demand from students with disabilities, visibility of information for students with disabilities, use of the support unit, among others).

Overall, although the university's online response to students with disabilities has been assessed as satisfactory, the area of learning materials has received a lower rating and this should therefore be one of the central focuses. Learning resources represent a challenge for the university in terms of improving its multimodal approach as well as for the ICT industry in terms of enhancing content accessibility and offering a higher level of diversification in the educational delivery. Another aspect to be improved, according to the results, is the online teaching support given to students with disabilities. In this regard, it is important to obtain the opinions of the online teachers to complement those of the students. Thus, further steps in the research should focus on obtaining both sets of data - from students and teachers - and interpret the results as a whole. Moreover, and having observed that there is no much teacher training in this area, it is essential that specific teaching assistance training courses are designed so that the institution can adapt its online teaching process to students with disabilities.

In summary, in terms of results, in this research it can be said that the university attracts and heeds the needs of students with disabilities but lacks specific support for students with certain kinds of disabilities, especially those with mental illnesses, who, in line with the literature, most often appear not to be properly attended to or may even seem invisible (Kent, 2015). In this respect, and pending a more accurate scale to assess readiness, the point could be made that the 
university presents a medium-high level of disability readiness, as it shows development in this area and user satisfaction in a real scenario.

In terms of tools, the research also reveals the soundness of the three aspects of analysis as an embryo of a possible scale of levels of online readiness, which would help the universities assess their maturity in this field and also design a progressive plan for the logical steps that a university should take in adapting how it responds to the diversity of learners.

\section{Acknowledgments}

We thank all the students who completed the survey and are grateful for the help of the UOC's Accessibility Program in contacting them; had it not been for this help, we would not have been able to reach the students.

\section{References}

Adams, R. J. (1973). Building a foundation for evaluation of instruction in higher education and continuing education. PhD dissertation, The Ohio State University. Retrieved from: http://www.ohiolink.edu/etd/

Alahmadi, T., \& Drew, S. (2017). An evaluation of the accessibility of top-ranking university websites: Accessibility rates from 2005 to 2015. Journal of Open, Flexible, and Distance Learning, 21(1), 7-24. Retrieved from: https://www.learntechlib.org/p/180233/.

Alamri, A., \& Tyler-Wood, T. (2017). Factors Affecting Learners with disabilities-Instructor Interaction in Online Learning. Journal of Special Education Technology, 32 (2), 59-69. doi: 10.1177/0162643416681497

Arachchi, T. K., Sitbon, L., \& Zhang, J. (2017). Enhancing Access to eLearning for People with Intellectual Disability: Integrating Usability with Learning. In R. Bernhaupt et al. (eds). INTERACT Proceedings 2017, Part II, LNCS 10514. Springer International Publishing (pp. 13-32). doi: 10.1007/978-3-319-67684-5_2

Betts, K. S. et al. (2012). Strategies to Increase Online Student Success for Students with Disabilities. Journal of Asynchronous Learning Networks, 17 (3), 49-63. Retrieved from: https://eric.ed.gov/?id=EJ1018265

Cindy A., Dell, T.F. \& Blackwell, T.L. (2015). Applying Universal Design for Learning in Online Courses: Pedagogical and Practical Considerations. Journal of Educators Online, 12(2), 166-192. Available at: https://eric.ed.gov/?id=EJ1068401

Crow, K.L. (2008). Four types of disabilities: Their impact on online learning. Techtrends: Linking Research \& Practice To Improve Learning, 52(1), 51-55. doi: 10.1007/s11528-008-0112-6

Fichten, C.S. et al. (2009). Disabilities and e-Learning Problems and Solutions: An Exploratory Study. Educational Technology \& Society, 12(4), 241-256. Available at: https://eric.ed.gov/?id=EJ860448

Finn, L. L. (1998). Students' perceptions of beneficial LD accommodations and services at the postsecondary level. Journal of Postsecondary Education and Disability, 13, 46-67. doi: $10.1080 / 15377903.2013 .751477$

Griful-Freixenet, J., K. et al. (2017). Higher education students with disabilities speaking out: perceived barriers and opportunities of the Universal Design for Learning framework. Disability \& Society, 32(10), 1627-1649. doi: 10.1080/09687599.2017.1365695

Ilgaz, H., \& Gulbahar, Y. (2017). Why Do Learners Choose Online Learning: The Learners' Voices. In M.B. Nunes, \& M. McPherson (eds). Proceedings International Association for Development of the Information Society (IADIS) International Conference on E-Learning (pp. 130-136). Retrieved from: https:// eric.ed.gov/?id=ED579379 
Jo, I.H. et al. (2015). Relations between student online learning behavior and academic achievement in higher education: A learning analytics approach. In C. Guang et al. (eds.). Emerging issues in smart learning, Berlin: Springer (pp. 275-287).

Kent, M. (2015). Disability, Mental Illness, and eLearning: Invisible Behind the Screen? The Journal of Interactive Technology and Pedagogy, 8. Retrieved from: https://jitp.commons.gc.cuny.edu/disabilitymental-illness-and-elearning-invisible-behind-the-screen/

Knight, W., Wessel, R.D., \& Markle, L. (2018). Persistence to graduation for students with disabilities: Implications for performance-based outcomes. Journal of College Student Retention: Research, Theory and Practice, 19(4), 362-380. doi: 10.1177/1521025116632534

Kutscher, E.L., \& Tuckwiller, E.D. (2018). Persistence in higher education for students with disabilities: a mixed systematic review. Journal of Diversity in Higher Education, 12(2), 136-155. doi: 10.137/dhe0000088

Leake, D. (2015). Problematic data on how many students in postsecondary education have a disability. Journal of Postsecondary Education and Disability, 28, 73-78. Retrieved from: https://eric.ed.gov/? $\underline{\mathrm{id}=\mathrm{EJ} 1066327}$

Lee, I.H. et al. (2015). Postsecondary Education Persistence of Adolescents With Specific Learning Disabilities or Emotional/Behavioral Disorders. The Journal of Special Education, 49(2), 77-88. doi: $10.1177 / 0022466914524826$

Lopes, C. (2007). Evaluating e-learning readiness in a health sciences higher education institution. In M.B. Baptista Nunes, \& M. McPherson (eds). Proceedings of IADIS International Conference of e-learning, eds Retrieved from: http://www.iadisportal.org/e-learning-2007-proceedings

Mafenya, P. N. (2013). An investigation of first-year students' pedagogical readiness to e-learning and assessment in open and distance learning: An University of South Africa Context. Mediterranean Journal of Social Science, 4(13), 353-360. Retrieved from: http://www.mcser.org/journal/index.php/mjss/ article/view/1522/1536

McManus, D., Dryer, R., \& Henning, M. (2017). Barriers to learning online experienced by students with a mental health disability. Distance Education, 38(3), 336-352. doi: 10.1080/01587919.2017.1369348

Mosa, A.A., Mahrin, M.N., \& Ibrrahim, R. (2016). Technological aspects of e-learning readiness in higher education: A review of the literatura. Computer and Information Science, 9(1), 113-127. doi: 10.5539/ cis.v9n1p113

Newman, L.A., \& Madaus, J.W. (2014). Reported accommodations and supports provided to secondary and postsecondary students with disabilities: National perspective. Career Development and Transition for Exceptional Individuals, 38, 173-178. doi: 10.1177/2165143413518235

Nulty, D.D. (2008). The adequacy of response rates to online and paper surveys: what can be done? Assessment \& Evaluation in Higher Education, 33(3), 301-314. doi: 10.1080/02602930701293231

Oketch, H.A., Njihia, J.M., \& Wausi, A.N. (2014). E-learning readiness assessment model in Kenya's higher education institutions: A case Study of University of Nairobi. International Journal of Scientific Knowledge, 5 (6), 29-41. Retrieved from: https://profiles.uonbi.ac.ke/njihia/files/ elearning readiness assessment_model_in_kenya.pdf

Pittman, C.N., \& Heiselt, A.K. (2014). Increasing Accessibility: Using Universal Design Principles to Address Disability Impairments in the Online Learning Environment. Online Journal of Distance Learning Administration, 17(3). Retrieved from: https://eric.ed.gov/?id=EJ1044112

Radovan, M., \& Perdih, M. (2016). Developing Guidelines for Evaluating the Adaptation of Accessible Web-Based Learning Materials. IRRODL, 17(4). Retrieved from: http://www.irrodl.org/index.php/irrodl/article/view/ $\underline{2463 / 3810}$

Raja, D.S. (2016). Bridging the Disability Divide Through Digital Technologies. In World Development Report 2016: Digital Dividend's. Washington D.C.: World Bank [online] Retrieved from: http:// pubdocs.worldbank.org/en/123481461249337484/WDR16-BP-Bridging-the-Disability-Divide-throughDigital-Technology-RAJA.pdf 
Roberts, J.B., Crittenden, L.A., \& Crittenden, J.C. (2011). Students with disabilities and online learning: a crossinstitutional study of perceived satisfaction with accessibility compliance and services. Internet and Higher Education, 14, 242-250. Retrieved from: https://eric.ed.gov/?id=EJ946504

Rogers-Shaw, C., Carr-Chellman, D.J., \& Choi, J. (2018). Universal Design for Learning: Guidelines for Accessible Online Instruction. Adult Learning, 29(1), 20-31. doi: 10.1177/1045159517735530

Rohayani, A., Kurniabudi, K., \& Sharipuddin, S. (2015). A literature review: Readiness factors to measuring elearning readiness in higher education. International Conference on Computer Science and Computational Intelligence. Procedia Computer Science, 59, 230-234. doi: /10.1016/ j.procs.2015.07.564

Saekow, A., \& Samson, D. (2011). E-learning readiness of Thailand's Universities comparing to USA's cases. International. Journal of e-education, e-business, e-management and e-learning, 1(2). Retrieved from: http://www.ijeeee.org/Papers/020-Z0001.pdf

Tobin, T. J. (2014). Increase online student retention with universal design for learning. The Quarterly Review of Distance Education, 1(5), 13-24. Retrieved from: https://eric.ed.gov/?id=EJ1144189

Verdinelli, S., \& Kutner, D. (2016. 'Persistence Factors among Online Graduate Students with Disabilities. Journal of Diversity in Higher Education, 9(4), 353-368. doi: 10.1037/a0039791

UDI Online Project (2010). Students with disabilities and online learning. University of Connecticut, Center on Postsecondary Education and Disability. Retrieved from: https://cped.uconn.edu/udi/

Waterfield, B., Beagan, B.B., \& Weinberg, M. (2018). Disabled academics: a case study in Canadian universities. Disability \& Society, 33(3), 327-348. doi: 10.1080/09687599.2017.1411251

Weis, R., Dean, E.L., \& Osborne, K.J. (2016). Accommodation Decision Making for Postsecondary Students With Learning Disabilities: Individually Tailored or One Size Fits All? Journal of Learning Disabilities, 49(5), 484-498. doi: $10.1177 / 0022219414559648$

Whetstone, K.W. (2017). Upholding Accessibility Standards When Selecting Tech Tools. 50th Annual Conference ASCUE Proceedings (pp. 67-76). Retrieved from: https://files.eric.ed.gov/fulltext/ED575952.pdf 


\section{Appendix}

Online learning and disability at the UOC

Please contact adaptaUOC@uoc.edu if you have any issues accessing or answering the survey.

By completing this survey, I acknowledge that:

- I have read the information sheet provided in the email inviting me to participate and that I have been informed of and understand the purpose of this research.

- I have been given an opportunity to ask questions and seek further information about the study.

- I understand that I can withdraw at any time without prejudice.

- Any information that could potentially identify me will not be used in published material.

By submitting this survey, I hereby consent to take part in the study as outlined to me.

1. In what year were you born? (Enter 4-digit birth year: for example, 1976)

2. What is your gender?

Female

Male

Prefer not to say

Other (please specify)

3. What is the highest level of education you have completed or the highest degree you have received?

Primary school

Secondary school or equivalent

Some incomplete college or university studies (no degree)

Associate degree

Bachelor's degree

Master's or postgraduate degree

Other (please specify)

4. What type of disability or impairment, if any, do you have?

Hearing

Vision

Mental illness

Learning

Medical

Intellectual

Mobility

Acquired brain injury

Other (please specify) 
5. How long have you been a student at the UOC?

Less than one year

1 year

2 years

3 years

4 years

5 years

6 years

7 years

8 years

9 years

10 years or more

6. What is your chosen field of study?

Arts \& Humanities

Business

Law

Communication

Education

Health Science

Science and Engineering

Other (please specify)

7. Do you know the type of accommodations that can be offered in relation to your disability to help with your studies?

Yes

No

Unsure

8. Have any accommodations been made in relation to your disabilities in connection with your studies?

With all courses

With most courses

With some courses

With no courses

No accommodations needed

8a. What sort of accommodations has been made for you?

Content adaptations

Learning format materials

Teacher support and assistance

Assessment activities (PACs)

Exam/virtual test

Technology support

Other (please specify)

9. Did you find that the accommodations made were adequate and appropriate?

Yes, always

Mostly

Sometimes

Never

No accommodations have been made

Open comments: 
10. As part of your studies at the UOC, have you disclosed that you have a disability?

Always

Often

Sometimes

Rarely

Never

10b. When did you provide information about your disability?

(Select as many options as required)

Enrolment process

In certain courses during the regular learning process

In all courses

Due to a difficulty regarding an online class

10c. To whom did you provide information about your disability?

(Select as many options as required)

To the tutor

To the course instructor

To the courses' coordinating professors

To other students

To administrative staff

Other (please specify)

11. When you have not disclosed that you have a disability what are the factors that caused this? I did not think it would help

I did not know I could

I did not know how

I did not need any accommodations

I did not want any accommodations

I did not want to disclose my disability

Other (please specify)

12. Why have you chosen online learning?

Flexible schedule

Autonomy

Have other responsibilities

More adapted to my disability

Other (please specify)

13. How do you access the Internet for your studies?

Desktop computer

Laptop computer

IPad/tablet

Smartphone

Other (please specify)

14. Have you had any problems accessing online learning platforms to study at the UOC because they were not accessible enough?

Yes

No 
15. If yes, which platforms have you experienced difficulty with?

UOC Virtual Campus

Not used No problems Minor problems Major problems Unusable

Moodle

Blackboard

Facebook

Twitter

SlideShare

Prezi

Lectopia

Echo 360/Echo Centre

PDFs

Blogger

WordPress

WebCT

YouTube

Other (please specify)

16. Please list any other online platforms that you have had trouble accessing as part of your studies at the UOC

[Open field]

16a. Do you use any specific software to study?

Yes

No

16b. If yes, which ones?

[Open field]

16c. Do you use any specific hardware or devices to study?

Yes

No

$16 d$. If yes, which ones?

[Open field]

17. Would you recommend the UOC as a place to study for people with disabilities?

Yes

No

Maybe

17a. Have you ever found that you could not keep up with your classmates due to a lack of accessibility of the UOC's online learning environment, teaching or materials?

Yes

No

17b. If you have had difficulties, what were they?

[Open field] 
17c. Have you had to drop out of a programme, course or continuous assessment test due to a lack of accessibility of the online learning environment, teaching or materials?

Yes

No

17d. Rate from 1 to 10 ( $1=$ of little importance, $10=$ extremely important) the importance of the online learning environment being accessible when choosing what university to study at.

$$
\begin{array}{cccccccccc}
1 & 2 & 3 & 4 & 5 & 6 & 7 & 8 & 9 & 10 \\
0 & 0 & 0 & 0 & 0 & 0 & 0 & 0 & 0 & 0
\end{array}
$$

17e. Give two recommendations to improve the accessibility of the UOC's learning environment, teaching or materials.

[Open field]

18. Would you will be willing to participate in later stages of this research, including online focus groups or interviews? If so please leave your email address. Please contact adaptaUOC@uoc.edu

Please note that interviews and focus groups are not part of the survey and further participation is strictly voluntary (you can also change your mind and decide not to participate at any point). 